\title{
ON CIRCULATION OF INDIAN OCEAN WATERS EAST OF MALDIVES DURING THE POST MONSOON PERIOD
}

\author{
C. P. RAMAMIRTHAM \\ Central Marine Fisheries Research Institute, Cochin-18.
}

\begin{abstract}
The circulation patterns in the Maldive region between the $71^{\circ}$ and $80^{\circ} \mathrm{E}$ meridians within the equator and $8^{\circ} \mathrm{N}$ are discussed. It is observed that a large cyclonic gyre exists in the northern regions and an anticyclonic one in the souther region, mainly in the subsurface layers. These are supposed to be associated with divergence and convergence phenomena occurring in the area. The influence of the Maldive islands and the associated bottom topography in the formation of these circulation patterns is indicated.
\end{abstract}

\section{INTRODUCTION}

Studies of the circulation patterns in an area form an important branch in Physical Oceanography since such studies facilitate the determination of the areas of convergence and divergence in the ocean, which are of important consequence to the fertility and thus to the fisheries of the region, (Hela and Laevastu 1961). In the present account, the circulation patterns in the area between the equator and $8^{\circ} \mathrm{N}$ latitude, within the meridians of $71^{\circ}$ and $80^{\circ} \mathrm{E}$ in the region east of the Maldive islands are considered. The vertical distribution of hydrographic properties in the area has already been published, (Ramamirtham 1968), but the circulation patterns were not discussed in detail. The data pertaining to this were collected by the Central Marine Fisheries Research Institute during the cruises of $R$. V. Varuma from 15 September-16 October1962 as part of the IIOE Programme. Deep-sea observations were available which permitted the application of the geostrophic method to the study of the circulation patterns. A comparison between the geostrophic circulation patterns and those observed from distribution of hydrographic properties is also made. Isentropic studies, rather, the studies of the topography of the articular Sigma-T surfaces (Montgomery 1937), were also made to confirm the circulation patterns.

\section{METHODS}

The specific volume anomalies at 40 stations were calculated using an Oceanographic Slide Rule, and the dynamic height anomalies were calculated there from. The $1000 \mathrm{db}$. surface was chosen as the level of zero horizontal motion. 
In the present analysis a difficulty arises as to whether or not the geostrophic method would be valid in the equatorial region, since the Coriolis force vanishes there. But Ramanov (1961) gives some general considerations of the current computations in the equatorial part of the Indian Ocean and states that rather good comparison of results is noticed between observed current velocities (at dam-buoy stations) and the computed current velocities in the equatorial regions for horizontal $200,300,800$, and $900 \mathrm{~m}$. At deeper depths, sharp differences were noticed. The present investigations pertain to depths less than $1000 \mathrm{~m}$ only and to north of $1^{\circ} \mathrm{N}$ and thus the dynamical studies have been made in conjunction with other methods. The vertical distribution patterns of dynamic depth anomaly have also been made although the distribution charts have not been presented.

\section{ObSERVATIONS}

Considering first the temperature distribution in trorizontal, it can be noticed that more or less uniform distribution prevailed at the surface, (Fig. 1-A), except for a weakly developed tow temperature cell near the Wadgebank area. Similar more or less isothermal patterns existed at 20 and $30 \mathrm{~m}$ depths. But unlike the surface and subsurface temperature patterns, an anticyclonic gyre around $2^{\circ} \mathrm{N}$ and a cyclonic one north of it could be inferred from the dynamic topography chart, (Fig. 2-A). The dynamic topography at $50 \mathrm{~m}$ depth (Fig. 2-B) was similar to that at surface as can be seen from the figure. At $50 \mathrm{~m}$ depth, the temperature distribution also gives an additional clue as to the formation of the cyclonic gyre (Fig. 1-B), although the anti-cyclonic one was not evident as in the topography chart.

At the $75 \mathrm{~m}$ isobaric level the cyclonic gyre has well developed with increased intensity and has occupied a large area as can be seen from the figure (fig. 1-C). The temperature gradients are also quite strong. Thus the gyre spreads between the area from $74^{\circ}$ to $80^{\circ} \mathrm{E}$, between the latitudes of $3^{\circ}$ and $8^{\circ} \mathrm{N}$. But unlike the $50 \mathrm{~m}$ level, the formation of an anticyclonic movement can be observed at $75 \mathrm{~m}$, in the temperature distribtuion between $2^{\circ}$ and $2^{\circ} 30^{\circ} \mathrm{N}$, to the east of the $76^{\circ} \mathrm{E}$ meridian. Both the circulation patterns are mostly confined to the east of the Maldives Archipelago. A reference to the geopotential topography (Fig. 2-C) gives more evidence as to the formation of this anticyclonic gyre with more intensity. A closed pattern is observed, and due southwest of Ceylon the continuation of this as merging with the cyclonic gyre can be observed.

With the existence of these circulatory movements, another anticyclonic eddy is observed due west of the island chain, (Fig. 1-D). An additional cyclonic movement could be observed at 75 and $100 \mathrm{~m}$ depths in the region just north of the equator between $76^{\circ}$ and $78^{\circ} \mathrm{E}$. This is more clearly perceptible at $100 \mathrm{~m}$ 


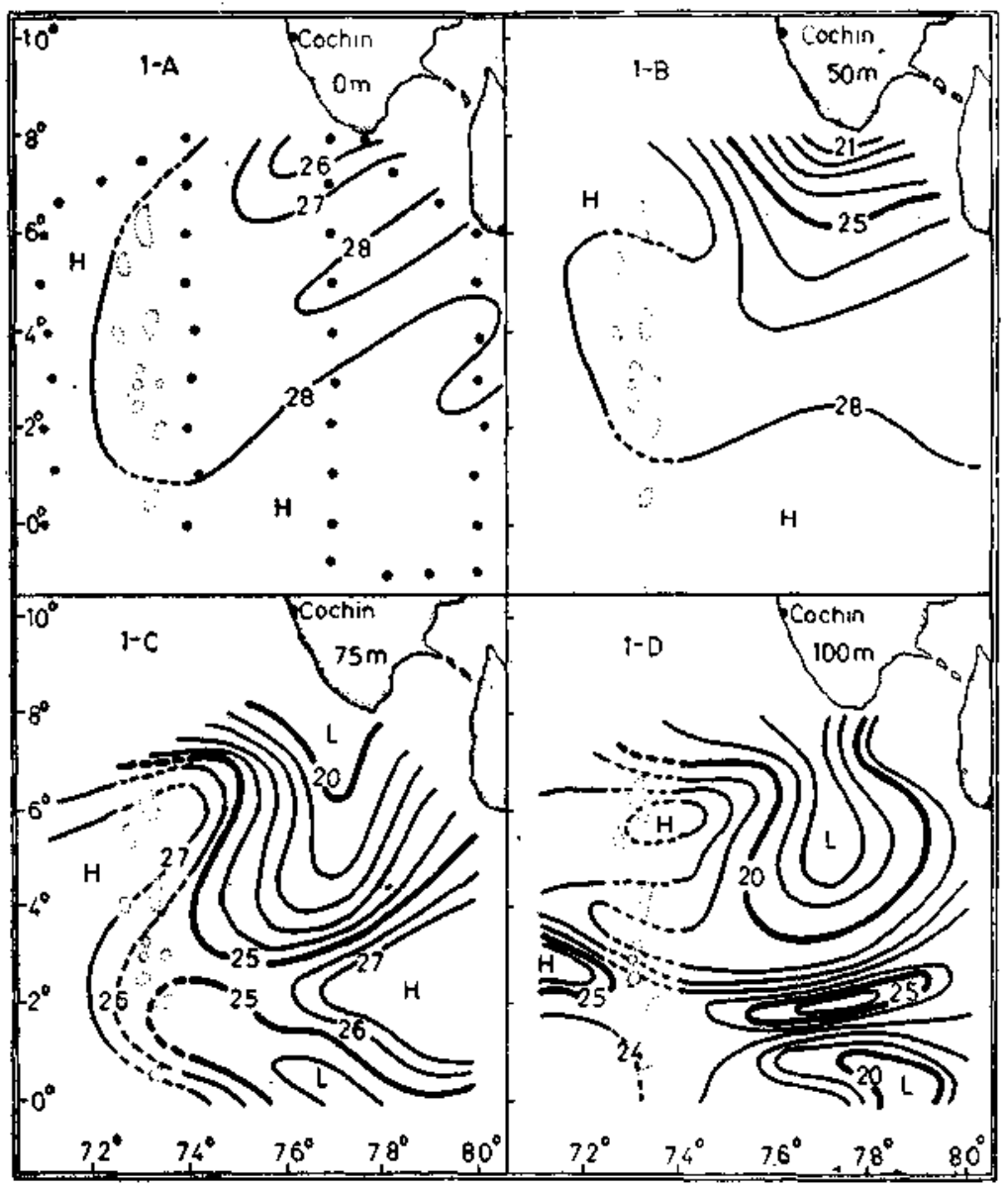

FIG. 1. Distribution of temperature at different isobaric levels in the Maldive region.

depth than at $75 \mathrm{~m}$. The topographic chart (Fig. 2-C and Fig. 2-D), offers additional clue for the patterns observed from temperature distribution, the dynamic heights decreasing towards the equator. The continuation of the anticylonic gyre as merging with the cyclonic one due southwest of Ceylon is observed at $100 \mathrm{~m}$ depth as well.

As an additional confirmation the topography of the Sigma-T surface (nearly isentropic surfaces) for the Sigma- $T$ values of $23.5,24.0,24.5$, and 25.0 were charted out. These are presented in figure 3 . The cyclonic gyre is clearly evident from the figures and the eastward drift along $3^{\circ} \mathrm{N}$ branching towards north and south around the $79^{\circ} \mathrm{E}$ meridian helping the formation of the circulatory movements is observed. It is again noticeable that the spatial extent of the cyclonic gyre is much more than that of the anti-cyclonic one. 


\section{Discussion}

From the foregoing observations it can be inferred that during the postmonsoon period there exist two large gyres in the region between the Maldives Archipelago and the $80^{\circ} \mathrm{E}$ meridian within equator and $8^{\circ} \mathrm{N}$. A general insight into the bottom topography of the oceanic region around the Maldives reveals the presence of a meridional ridge running from equator roughly up to $7^{\circ} \mathrm{N}$, except for very deep portions near $2^{\circ} \mathrm{N}$ and $5^{\circ} 13^{\prime} \mathrm{N}$ latitudes, (John Murray expedition Reports, 1933-34). The 300 fathom line around the Archipelago encircles a long bank from $2^{\circ}$ to $6^{\circ} \mathrm{N}$ whose width is on an average 40-50 nautical miles, within which the main group of jslands is located. Thus the influence of the islands and the associated bottom topography around them cannot be ignored when a study of the circulation patterns in this region is contemplated. Investigating on these lines, it is possible that the large cyclonic

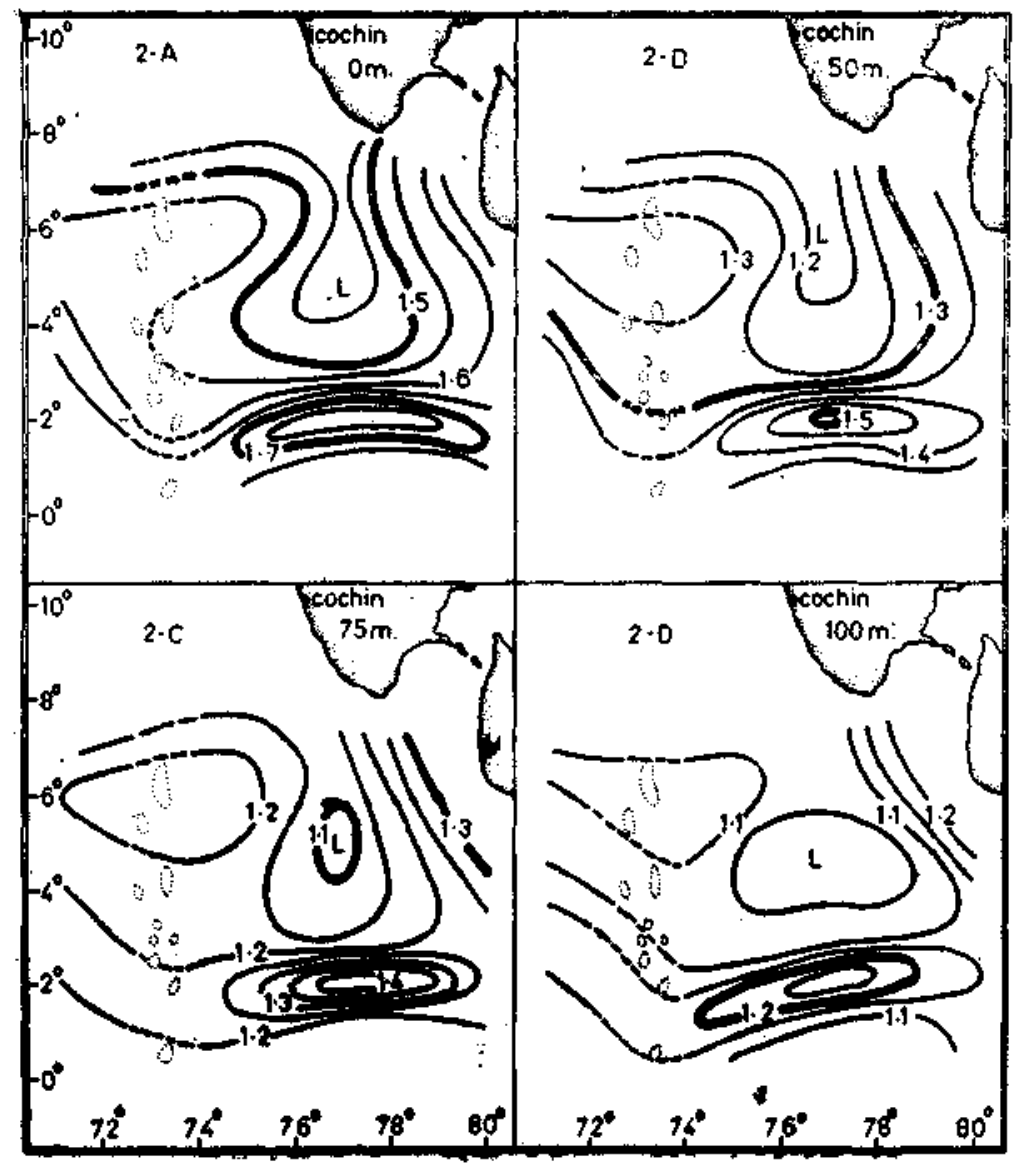

FIG. 2. Geopotential topography of different isobaric tevels in the Maldive region. (Contour intervel 0.05 dym. meter) 
eddy in the northern region and the anticyclonic one south of it, may be the results of deflection of linear currents by the island chain, and the influence of the associated bottom topography.

Another peculiarity of these systems is that they are clearly perceptible from 50 to $100 \mathrm{~m}$ only, i.e., they extend from the top of the thermocline to about bottom of the same, as far as the temperature distribution is concerned. It is thus possible that these refer to divergence and convergence zones, better developed in the subsurface layers, during the postmonsoon season. In earlier works, (Ramasastry and Myrland 1960, Ramamirtham and Rao 1973) it has been observed that a southward drift along the west coast of India exists during the peak monsoon and postmonsoon seasons. This forms part of the large anticyclonic system developed in the Arabian Sea consisting of the currents along

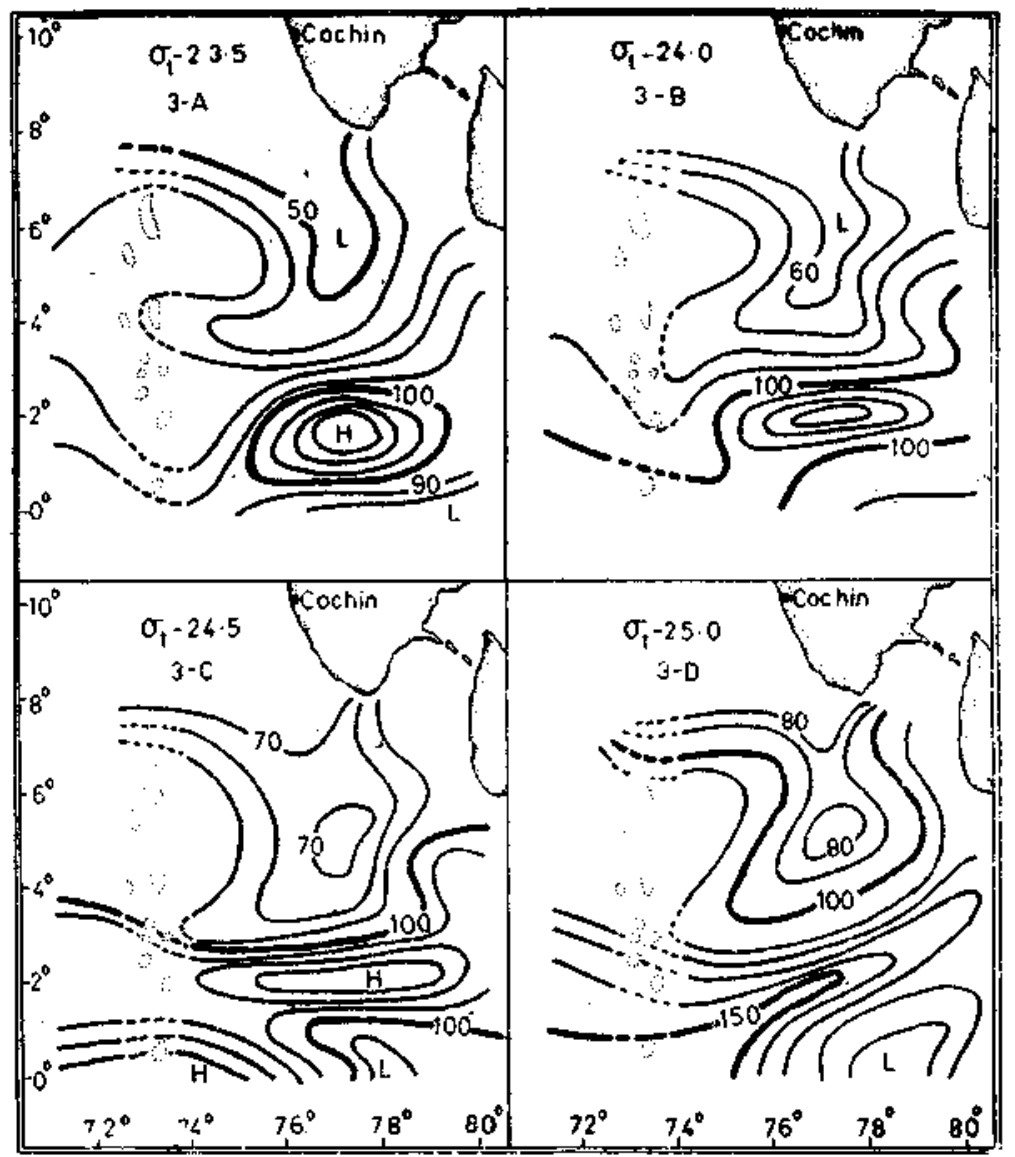

Fic. 3. Topography of selected isentropic $\left(\sigma \frac{-}{t}\right)$ surface in the Maldive region, in meters. 
Somali Coast. It is possible that part of this major circulation may be hitting the Maldives Archipelago while running due southwest of India, and forming the divergence zone. When the coastal current turns west around the Wadgebank area (off Cape Comorin) a sort of divergence may be produced there and this also can help the formation of the large divergence zone observed. Jayaraman et al (1960) while discussing the hydrography of the Laccadive offshore waters during summer, have stated that the main type of motion detectable is the circulatory motion and it is seen to be present around each of the islands, and this type of motion is seen to be present from surface downwards to the discontinuity layer.

The Hugh $M$. Smith cruises in the Hawaiian offshore waters have also revealed the presence of similar corculatory movements round the islands (McGary 1955, Cockel 1955). Thus the influence of an island chain in modifying the circulation patterns in its viscinity is clearly elucidated and thus in the present context also the influence of the Maldives cannot be overlooked. Bruce (1968) has stated that the summer geopotential topography off the Somali and Arabian coasts in the western Indian Ocean, indicates that relatively small but intense anticyclonic gyres were formed during this period, and the major circulation pattern and their variations were considerably greater in the upper $220 \mathrm{~m}$ column. In the present case also the major circulation patterns could be observed only in the upper $150 \mathrm{~m}$ and the waters were mostly static below this level.

It has been observed earlier that the dynamic topographies, topography of the isentropic surfaces, and the thermal fields present comparable type of circulation only below a depth of $75 \mathrm{~m}$ and the discripancy in the upper layers $(0-50 \mathrm{~m})$ is inferred as due to the effect of salinity as observed earlier (Ramamirtham 1966). In the present case also, similar type of circulation exists from $50 \mathrm{~m}$ downwards only when the thermal and topographic charts are compared and thus the effect of salinity in the upper layers can be inferred. Hikosaka and Watenabe (1955) while discussing the divergence and convergence phenomena in the north-western Pacific Ocean, mention that the areas of convergence are extensively located in the regions between the equatorial divergence area and clongated divergence areas. In the Maldive region, if a reference is made to the dynamic topography charts in general, and to the temperature distribution at 75 and $100 \mathrm{~m}$ in particular, it can be observed that the convergence zone along $2^{\circ} \mathrm{N}$ is invariably juxtaposed between the large divergence zone due north of it and a less intense one observed at about $0^{\circ} 30^{\prime} \mathrm{N}$, due south of it. The topography of the isentropic surface also offer more evidence as to the formation of these vergence zones. Reference may be made to the work conducted by $K$. V. Sundararamam and K. V. Sreeramamurthi (1967) in the Eastern Indian Ocean, These authors, while discussing the dynamic topography of the isobaric levels in the Eastern Indian Ocean near about the Maldive region observed an eastward flow around $7^{\circ} \mathrm{N}$ and a westward one around $1-2^{\circ} \mathrm{N}$ during the July- 
August period (viz., the peak monsoon period). Their observations were extended up to $78^{\circ}$ East and in the present case the observation has been extended up to $80^{\circ} \mathrm{E}$ by which the influence of the West Coast of Ceylon can also be observed. Moreover, the present observations being in September-October period there is all probability of the above mentioned fiow patterns transformed into large gyres, by progress of season. Again these authors have stated that the monsoon current and equatorial counter-currents join and attain bigh speed south of Indian peninsula and that the reflection of equatorial counter-currents in the Maldive region is due to the bottom configuration in this area. Thus the large cyclonic and anticyclonic gyres observed in the present case can in all probabilities be the extended patterns of the monsoon currents in this area.

\section{ACKNOWLEDGEMENTS}

The author wishes to express his thanks to Dr. E. G. Silas for his encouragement in such investigations. Thanks are also due to Dr. A. V. S. Murty for his suggestions during the course of the work. The author gratefully acknowledges the helps rendered by his colleagues Sarvashri D. S. Rao, R. Vasantakumar and P. M. Aboobaker, in processing and analysis of the data concerned.

\section{References}

Bruce, J, G. 1968. Comparison of the near surface dynamic topography during the two monsoons in the western Indian Ocean. Deep Sea Res. Vol. 15: 665-677.

Hela, Ilmo and Talvo Laevastu. 1961. Fisheries Hydrography: 43 \& 51 Fishing News (Books) L.td. London.

Jayaruman, R., C. P. Ramamirtham, K. V. Sundaramam and C. P. Aravindakshan NALR. 1960. Hydrography of the Laceadive Offishore waters, J. mar. biol, Ass. India, 2(1): 24-34.

JoHN MURRuY Expepition. 1933-34. Scientific Reports. Vol I - Introduction and Topography.

MCGAry, J. W. 1955. Mid Pacific Oceanography - Pant VI - Hawadian Offishore waters, December 1947 to November 1951. Spec. Sci. Rep. U.S. Fish Wildl. Serv., No. 152: 1-138.

MONTcomery. R. B. 1937. A suggested method for representing gradient flow in isentropic analysis. Bull. American Meteorological Soc. 210-212.

RamamirthaM, C. P. 1966. On the relative (geostrophic) currents in the southeastern Arabian Sea. J. mar. biot. Ass. India, 8(2): 236-243.

RAmamiRtham, C. P. AND D. S. RAo. 1973. On upwelling along the west coast of India. J. mar. biol. Ass. India., 15(1): 306-317.

Ramamirtham, C. P. 1968. Vertical distribution of temperature, salinity and dissolved oxygen in the Maldive region of the Indian Ocean. Indian J. Fish., 15: 27-39.

Ramasastry, A. A. and Per Mrrland. 1959. Distribution of temperature, salinity and density in the Arabian sea along the South Malabar Coast (South India) duriag the postmonsoon season. Indian J. Fish., 6(2): 223-225. 
Romanov, Ju. A. 1961. Dynamic method as applied to the equatorial Indian Ocean. Okeanol. No. 4: 25-30.

Seckel, G. R. 1955. Pacific Oceanography - Part VII - Hawaiian Offshore waters, Soptember 1952 to August 1953. Spec. Sci. Rep. U.S. Fish Wildl. Serv., No. 164: 1-249

Sigeo Hikosaka and RYuzo Watanabe 195.5. Areas of convergence and divergence of surface currents in the north-western Pacific. Proceedings of the UNESCO symposium on Physical Oceanography Tokyo, 101-103.

SUNdARARAMAM, K. V. AND SREERAmamuRthy. 1968. Geostrophic currents in the Eastern Arabian Sea during the monsoon season - Bull. Inst. Sci. India. No. 38 Patt I. 221-235. 